\title{
Examination of Maternal-based Familial Factors in Malnourished Pediatric Patients Without Illness- Dependent Cause: A Single-center Case-control Study
}

\author{
Hastalığa Bağlı Nedeni Olmayan Malnütrisyonlu Pediatrik Hastalarda Anne \\ Kaynaklı Ailesel Faktörlerin İncelenmesi: Tek Merkezli Olgu Kontrol Çalışması
}

\author{
Melike Ersoy¹, (D) Sena Saygılı Ok², (1) Semra Yılmaz², (1) Tuğçe Çetin³ \\ ${ }^{1}$ University of Health Sciences Turkey, Bakırköy Dr. Sadi Konuk Training and Research Hospital, Clinic of Pediatrics, Division of Pediatric \\ Metabolic Diseases, Istanbul, Turkey \\ 2University of Health Sciences Turkey, Bakırköy Dr. Sadi Konuk Training and Research Hospital, Clinic of Pediatric Child and Adolescent \\ Psychiatry, Istanbul, Turkey \\ ${ }^{3}$ University of Health Sciences Turkey, Bakırköy Dr. Sadi Konuk Training and Research Hospital, Clinic of Pediatrics, Istanbul, Turkey
}

\begin{abstract}
Objective: Insufficient weight gain is one of the most common complaints in pediatric outpatient clinics in Turkey. This study aimed to investigate the effects of maternal psychiatric problems and familial factors on malnutrition in their children.

Methods: A total of 34 mothers of malnourished children aged 016 years, who applied to the pediatric metabolism outpatient clinic without underlying organic disease and mothers of healthy individuals from the same age and gender group were included in the study. Sociodemographic status, Symptom Checklist-90, multidimensional scale of perceived social support (MSPSS), and scale for domestic violence against women scales evaluation results of both groups were compared.

Results: An illness-dependent cause of malnutrition was not found in 34 of 127 (26.7\%) patients. A statistical difference was found between the two groups in terms of educational status of parents, income level of the family, and work of the mother $(p=0.008, p=0.039, p=0.009$, and $p=0.004$, respectively). A statistical difference was found between the groups in terms of gestational week and the birth weight of the children $(p=0.006$ and $p=0.011$, respectively). The scores of cases who had planned pregnancy in the MSPSS were found to be statistically significantly higher than the cases without planned pregnancy $(p=0.012)$. The rate of depression, somatization, obsession, sensitivity, and anxiety symptoms in cases with moderate or severe malnutrition severity was found to be statistically significantly higher than the cases with mild malnutrition ( $p=0.039, p=0.029, p=0.028, p=0.028$, and $p=0.011$, respectively).
\end{abstract}

Conclusion: Parental education level, mother's working status, income level, mother's environmental support, and child's birth weight were determined as factors affecting the children's nutritional status, malnutrition type, and severity by causing effects on maternal psychology.

Keywords: Childhood malnutrition, maternal psychopathology, familial factors

\section{öz}

Amaç: Yetersiz kilo alımı Türkiye'de çocuk polikliniklerine başvurularda en sık görülen şikayetlerden biridir. Bu çalışmada annenin psikopatolojik durumu ve ailesel faktörlerin çocuklardaki malnütrsiyona etkisini araştırmayı amaçladık.

Gereç ve Yöntem: Pediyatrik metabolizma polikliniğine başvuran, altta yatan organik bir hastalığı olmayan 0-16 yaş arası malnütrisyonlu çocuğu olan 34 anne ile aynı yaş ve cinsiyet grubundan sağlıklı bireylerin anneleri çalışmaya dahil edildi. Her iki grubun sosyo-demografik durumları, Belirti Tarama testi-90, çok boyutlu algılanan sosyal destek ölçeği (ÇBASDÖ) ve kadına yönelik aile içi şiddet ölçeği (KYAişÖ) değerlendirme sonuçları karşılaştırıldı.

Bulgular: Anne ve babanın eğitim durumları, ailenin gelir düzeyi, annenin çalışması konularında her iki grup arasında istatistiksel anlamlı fark saptandı $(p=0,008 ; p=0,039 ; p=0,009 ; p=0,004)$. Çocukların doğum haftası ile doğum kiloları arasında gruplar arası anlamlı fark saptandı

Address for Correspondence: Melike Ersoy, University of Health Sciences Turkey, Bakırköy Dr. Sadi Konuk Training and Research Hospital, Clinic of Pediatrics, Division of Pediatric Metabolic Diseases, Istanbul, Turkey

Phone: +0 2124142000 E-mail: zeynepcey@hotmail.com ORCID ID: orcid.org/0000-0002-2316-0790

Cite as: Ersoy M, Saygılı Ok S, Yılmaz S, Çetin T. Examination of Maternal-based Familial Factors in Malnourished Pediatric Patients Without

Illness-Dependent Cause: A Single-center Case-control Study. Med J Bakirkoy 2021;17:343-353

Received: 24.08 .2021

Accepted: 09.11.2021 
( $p=0,006, p=0,011)$. Planlı gebelik yapan olguların anne ölçeği ÇBASDÖ alt boyutundan aldıkları puanlar, planlı gebelik yapmayan olgulara göre istatistiksel olarak anlamlı düzeyde yüksek saptandı $(p=0,012)$. Manütrisyon ağırlığı orta/ağır olan olguların depresyon, somatizasyon, obsesyon, duyarlılık ve kaygı belirtilerinin yüksek olması oranı, hafif olan olgulara göre istatistiksel olarak anlamlı düzeyde yüksek saptandı ( $p=0,039$, $p=0,029, p=0,028, p=0,028,0,011$ ).

Sonuç: Ebeveyn eğitim düzeyi, annenin çalışması, gelir düzeyi, annenin çevre desteği ve çocuğun doğum tartısı, anne psikolojisinde etkiye yol açarak çocukların nütrisyonel durumu, malnütrisyon tipi ve ağırlığı üzerinde etkili faktörler olarak belirlenmiştir.

Anahtar Kelimeler: Çocukluk malnütrisyonu, anne psikopatolojisi, ailesel faktörler

\section{INTRODUCTION}

Malnutrition refers to deficient or excess nutrient intake, imbalanced essential nutrients, or impaired nutrient utilization, according to the definition of the World Health Organization (WHO), which is still a common and priority health problem in the world today. Malnutrition is one of the leading problems of childhood because it opens the door to other diseases and causes intelligence quotient regression in the long term $(1,2)$. The bidirectional burden of malnutrition consists of both undernutrition and overweight and obesity, which is identified as diet-related non-communicable diseases. Undernutrition manifests in four broad forms: Wasting, stunting, underweight, and micronutrient deficiencies. Each form is expressed in the number of standard deviation (SD) units from the median of the WHO Child Growth Standards. Children are classified as malnourished if their z-scores are below minus two or minus three SD (-2 SD or $-3 \mathrm{SD})$ from the median of the WHO Child Growth Standards. Wasting is defined as low weight-for-height, which refers to when a child's weight is lower than the weight ratio of a healthy child of the same height and indicates acute malnutrition. Traditionally, severity degree is determined as normal at $90-110 \%$; mild at $80-90 \%$, moderate at $70-80 \%$, and severe at $<70 \%$ according to Gomez scoring system, which usually occurs when a person has not had adequate quality and quantity of food. Stunting is defined as low height-for-age due to chronic or recurrent undernutrition that is usually associated with poverty, poor maternal health, and nutrition, frequent illness, and/or inappropriate feeding and care in early life. Stunting blocks children from reaching their expected physical and cognitive potential. Underweight is defined as low weight-for-age and the child may be stunted, wasted, or both. Micronutrient deficiencies are a lack of vitamins and minerals that are essential for body functions such as producing enzymes, hormones, and other substances needed for growth and neurocognitive development. This article will use malnutrition as common terminology that includes wasting, underweight, and stunning.

Approximately $45 \%$ of deaths among children under 5 years of age are linked to malnutrition that mostly occurs in low- and middle-income countries (3). Malnutrition is directly related to the deaths of 300,000 children annually and is indirectly responsible for the deaths of 5 million children under the age of 5 . The prevalence of malnutrition varies between countries and even between regions of the same country. According to the 2020 data of the WHO, global stunting, underweight, and wasting prevalence under 5 years old is $21.3 \%, 13.5 \%$, and $6.9 \%$, respectively (4).

Food allergies, cystic fibrosis, malabsorption syndromes, genetic anomalies, inherited metabolic diseases, celiac disease, frequent recurrent infections, and immune deficiency syndromes are the leading medical causes $(5,6)$. Social, developmental, economic, and poor maternal psychological may cause insufficient calorie intake apart from illness-dependent causes $(7,8)$. Sometimes, more than one cause appears together. Malnutrition is a health problem; however, it may base on complex reticulated social problems. The cause-effect relationship becomes more complicated to resolve.

This study aimed to examine the relationship between maternal-based familial factors and malnutrition in pediatric patients.

\section{METHODS}

\section{Participants}

This is a single-center prospective study, which includes children who are admitted to the pediatric metabolism outpatient clinic between January 2021 and June 2021. Children aged 0-16 years whose height and weight measurements were -2 SD score (SDS) and those whose mothers volunteered for the study were included in the study. The control group consists of mothers of healthy individuals with age and gender-matched. Socio-demographic status, symptom checklist-90 (SCL-90), multidimensional scale of perceived social support (MSPSS), and scale for domestic violence against women (SDVAW) scales evaluation results of both groups were compared.

\section{Socio-demographic Data and Scales}

The individual and familial history and the developmental and Socio-demographic characteristics of cases were 
determined using a form that was prepared by the researchers and filled in by the interviewer at the interview.

\section{SCL-90-R}

The SCL-90-R is one of the most widely used and wellvalidated self-report scales to assess a broad range of psychological problems and symptoms of psychopathology (9). The scale was translated and adapted to Turkish by Dağ (10).

The scale consists of 90 items using a 5 -point scale (1 means "no problem" to 5 means "very serious") to measure the extent to which they have experienced the listed symptoms. The scale consists of 10 different subscales as follows: somatization, obsessive-compulsive disorder (OCD), interpersonal sensitivity, depression, anxiety, hostility, phobic anxiety, paranoid thought, psychoticism, and additional items.

The subscale scores are obtained by summing the scores of the answers given to the relevant items and dividing them by the number of items that make up that subscale. After adding the ratings (0-4 points) for each item for 90 items, the overall symptom level average is obtained by dividing the total score obtained by 90 . Total and subscale scores are $0-4$, and higher scores on the SCL-90-R indicate greater psychological distress. Parameters with a score $>1$ are considered high and an indication of important psychological problems.

\section{MSPSS}

MSPSS is a self-report measure of subjectively assessed social support that was developed by Zimet et al. (11). MSPSS is a 12-item self-assessment scale that has three subgroups, each consisting of four items as a family, friends, and a private person. A 7-point Likert-type scoring scale is from 12-84, with higher scores indicating high perceived social support. The reliability and validity of the Turkish version were evaluated (12).

\section{SDVAW}

The SDVAW was developed by Kilic (13) to measure domestic violence against women. The scale consists of 50 items and 5 subscales that consist of 10 items each. Subscales are physical, emotional; verbal, economic, and sexual violence. The SDVAW is scored as 1-3 Likert types, 34 items are scored straight and 16 items are reverse scored with a total score of 50-150. The total score obtained from the whole scale indicates the level of domestic violence against women.

\section{Statistical Analyses}

The Number Cruncher Statistical System 2007 (Kaysville, Utah, USA) program was used for statistical analysis.
Descriptive statistical methods (mean, SD, median, frequency, percentage, minimum, and maximum) were used in evaluating the study data. The conformity of the quantitative data to the normal distribution was tested using the Shapiro Wilk test and graphical examinations. Independent group t-test was used for the comparison of normally distributed quantitative variables between the two groups and the Mann-Whitney $U$ for comparisons between two groups of non-normally distributed quantitative variables. The Kruskal-Wallis and Dunn Bonferroni tests were used to compare the groups of more than two quantitative variables without normal distribution. The Pearson Chisquare, Fisher Exact, and Fisher-Freeman-Halton Exact test were used to compare qualitative data. The Pearson correlation analysis and Spearman correlation analysis were used to evaluate the relationships between quantitative variables. Statistical significance was accepted as a p-value of $<0.05$.

The study protocol was approved by the Ethics Committee University of Health Sciences Turkey, Bakırköy Dr. Sadi Konuk Training and Research Hospital (approved number: 2021/58; date: 01.02.2021). All patients agreed to participate in the study and written informed consents were obtained from each participant.

\section{RESULTS}

An illness-dependent cause of malnutrition could not be found in 34 of 127 (26.7\%) patients who applied to the outpatient clinic with the complaint of insufficient weight gain. The ratio of children who are underweight, wasting, and stunting was $32.3 \%, 41.2 \%$, and $26.5 \%$, respectively. The study is summarized with a flow chart, in Figure 1. The severity score of the cases as mild, moderate, and severe were $55.9 \%, 35.3 \%$, and $8.8 \%$, respectively. The mean age of the mothers participating in the study was $35.02 \pm 6.03$ years (range, 20-52). Group of malnourished cases $(n=34)$ and a group of healthy cases $(n=51)$ were compared according to the specified scales.

\section{Comparison of Socio-demographic Parameters According to Groups}

A statistically significant difference was found between the two groups in the educational status of parents, income level of the family, and the working status of the mother $(p=0.008, p=0.039, p=0.009$, and $p=0.004$, respectively). The rate of mothers of malnourished cases not going to school was found to be significantly higher, as well as the rate of mothers of the control group having a university degree. The rate of being a university graduate from the fathers of the control group was found to be significantly higher 
than those in the malnourished group. The rate of receiving wages below the minimum wage in the malnourished group was found to be significantly higher than those in the control group.

The rate of mothers of the malnourished group as housewives was found to be significantly higher, whereas the working rate of mothers of the control group was found to be significantly higher. No significant difference was found between the two groups in terms of age at marriage, age at first mother, and the number of children (Table 1).

\section{Distribution and Significance of Parameters Related to the Child by Groups}

Birth weights of patients in the malnourished group were statistically significantly lower than those in the control group ( $p=0.006$ ). In addition, a statistically significant difference was found between the delivery times of the cases according to the groups $(p=0.011)$. The rate of preterm birth at the time of delivery was found to be significantly higher in the malnourished group, whereas the rate of term birth was found to be significantly higher in the control group (Table 2).

\section{MSPSD, SDVAW, and SCL-90 total and Subscale Scores} Comparison of the Two Groups

No significant differences were observed between the two groups in terms of SDVAW ( $p=0.685), S C L-90$ total $(p=0.551)$, and subscales scores. However, the MSPSD scores of the mothers of the malnourished group were found to be statistically significantly lower compared to that

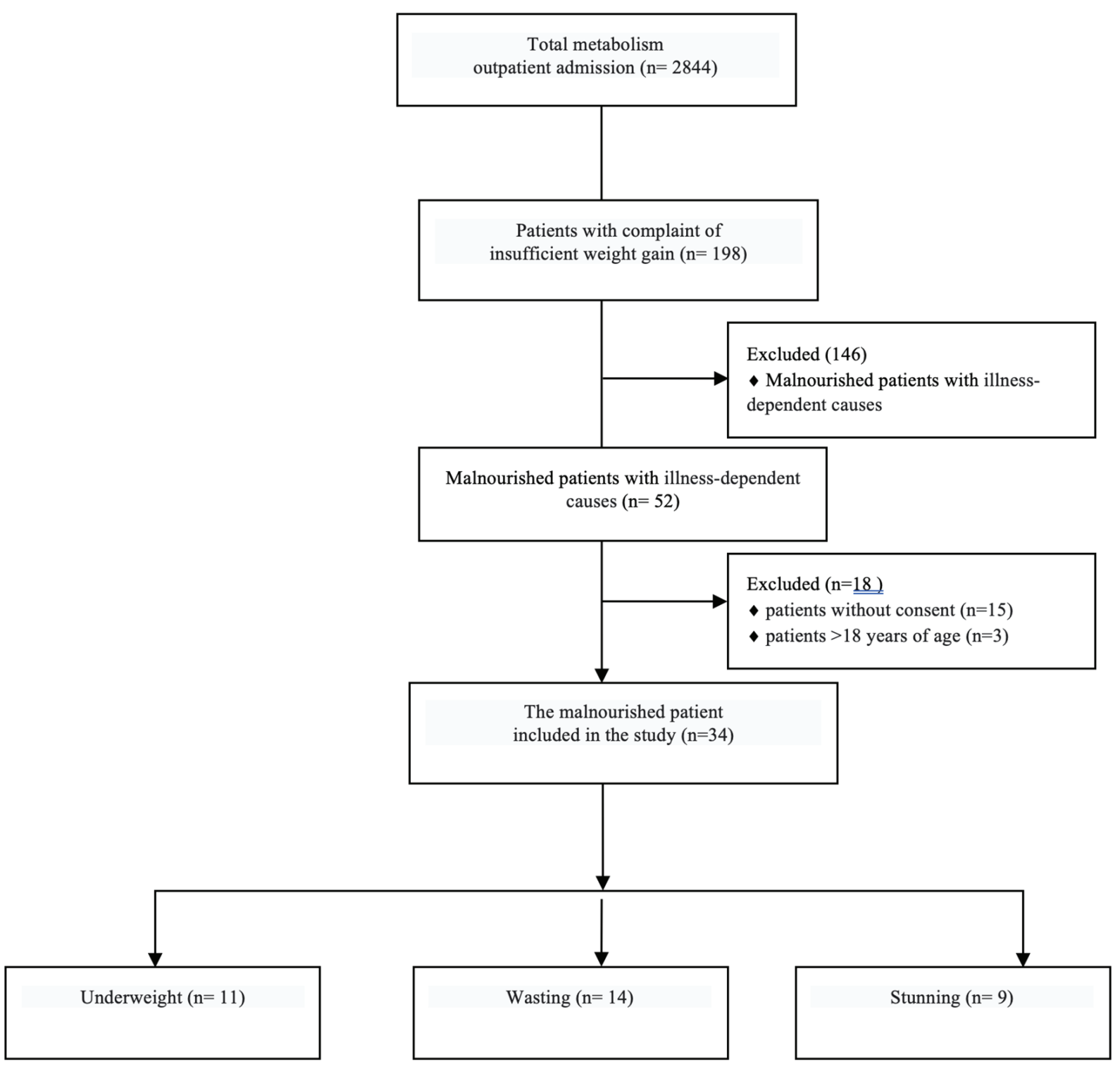

Figure 1. Study flow diagram 
of the control group ( $p=0.031$ ). In addition, the frequency of mothers with high scores on the anxiety subscale of the SCL90 was found to be significantly higher in the malnourished group (Table 3).

\section{Correlation of Mother Scale Scores and Child Parameters in Malnourished Cases Group}

A statistical difference was found between the SCL-90 phobic anxiety subscale score of mothers of term and

Table 1. Comparison of sociodemographic parameters according to groups

\begin{tabular}{|c|c|c|c|c|}
\hline & & Malnourished $(n=34)$ & Control $(n=51)$ & $\mathrm{p}$ \\
\hline \multirow{2}{*}{ Age (year) } & Mean \pm SD & $35.41 \pm 6.67$ & $34.76 \pm 5.62$ & 0.631 \\
\hline & - & 36.5 (20-49) & $34.0(22-52)$ & - \\
\hline \multirow{4}{*}{ Mother education; $\mathrm{n}(\%)$} & None & $7(20.6)$ & $2(3.9)$ & $0.008^{\star \star}$ \\
\hline & Primary school & $21(61.8)$ & $25(49.0)$ & - \\
\hline & High school & $4(11.8)$ & $10(19.6)$ & - \\
\hline & University & $2(5.9)$ & $14(27.5)$ & - \\
\hline \multirow{4}{*}{ Father education; n (\%) } & None & $4(11.8)$ & $1(2.0)$ & $0.039 *$ \\
\hline & Primary school & $22(64.7)$ & $26(51.0)$ & - \\
\hline & High school & $6(17.6)$ & $12(23.5)$ & - \\
\hline & University & $2(5.9)$ & $12(23.5)$ & - \\
\hline \multirow{4}{*}{ Mother working; n (\%) } & Housewife & $31(91.2)$ & $35(68.6)$ & $0.009 * *$ \\
\hline & Full time & $1(2.9)$ & $10(19.6)$ & - \\
\hline & Shift & $0(0.0)$ & $5(9.8)$ & - \\
\hline & Retired & $2(5.9)$ & $1(2.0)$ & - \\
\hline \multirow{4}{*}{ Father working; n (\%) } & Housewife & $7(20.6)$ & $4(7.8)$ & 0.078 \\
\hline & Full time & $21(61.8)$ & $33(64.7)$ & - \\
\hline & Shift & $1(2.9)$ & $9(17.6)$ & - \\
\hline & Retired & $5(14.7)$ & $5(9.8)$ & - \\
\hline \multirow{2}{*}{ Marital status; n (\%) } & Married & $33(97.1)$ & $47(92.2)$ & 0.644 \\
\hline & Divorced & $1(2.9)$ & $4(7.8)$ & - \\
\hline \multirow{5}{*}{ Income status; n (\%) } & Below minimum wage & $8(23.5)$ & $1(2.0)$ & $0.004^{\star \star}$ \\
\hline & Minimum wage & $12(35.3)$ & $14(27.5)$ & - \\
\hline & Minimum wage -3000 & $4(11.8)$ & $15(29.4)$ & - \\
\hline & $3000-5000$ & 7 (20.6) & $8(15.7)$ & - \\
\hline & $\geq 5000$ & $3(8.8)$ & $13(25.5)$ & - \\
\hline \multirow{3}{*}{ People live with; n (\%) } & Nuclear family & $25(73.5)$ & $39(76.5)$ & 0.925 \\
\hline & Extended family & $6(17.6)$ & $9(17.6)$ & - \\
\hline & Single parent with children & $3(8.8)$ & $3(5.9)$ & - \\
\hline \multirow[t]{2}{*}{ Marriage age } & Mean \pm SD & $21.38 \pm 5.19$ & $22.88 \pm 4.56$ & 0.164 \\
\hline & Median (min-max) & $20(13-38)$ & $22(15-34)$ & - \\
\hline \multirow[t]{2}{*}{ Maternal age } & Mean \pm SD & $23.82 \pm 5.48$ & $24.92 \pm 4.75$ & 0.329 \\
\hline & Median (min-max) & $24(16-40)$ & $24(17-35)$ & - \\
\hline \multirow[t]{2}{*}{ Number of siblings } & Mean \pm SD & $2.76 \pm 1.35$ & $2.27 \pm 0.98$ & 0.075 \\
\hline & Median (min-max) & $3(1-7)$ & $2(1-5)$ & - \\
\hline
\end{tabular}

${ }^{*} p<0.05,{ }^{* *} p<0.01, S D:$ Standart deviation, Min: Minimum, Max: Maximum, SD: Standart deviation, Min: Minimum, Max: Maximum 
preterm children in the malnourished group. Cases with preterm birth time in the phobic anxiety subscale were found higher than cases with term birth time. In addition, the MSPSD score of the mothers who had a planned pregnancy was found to be statistically significantly higher than the cases who did not have a planned pregnancy $(p=0.012)$.

Comparison of the type of Malnutrition and MSPSD, SDVAW, SCL-90 Total, and Subscale Scores in the Malnourished Group

No relationship was found between MSPSD, SDVAW, SCL-90 Total scores, and type of malnutrition. However, scores of the hostility subscale significantly differ according to the type of malnutrition ( $p=0.016$ ). According to the pairwise comparisons. Hostility subscale scores of the cases with the malnutrition type stunting were found to be significantly higher than the cases with the malnutrition type underweight.

Comparison of Malnutrition Severity and MSPSD, SDVAW, SCL-90 Total, and Subscale Scores in the Malnourished group

No statistical difference was found between the mild and moderate/severe groups in MSPSD, SDVAW, and SCL-90 total scores. However, depression subscale scores were found to be statistically significantly higher in mothers of moderate/severe cases compared to those with mild malnutrition ( $p=0.039$ ). In addition, the frequency of mothers with high scores on the somatization, $O C D$, interpersonal sensitivity, and anxiety subscale of the SCL-90 was found to

Table 2. Distribution and significance of parameters related to the child by groups

\begin{tabular}{|c|c|c|c|c|}
\hline & & Malnourished $(n=34)$ & Control $(n=51)$ & $\mathrm{p}$ \\
\hline \multirow{2}{*}{ Gender; n (\%) } & Female & $16(47.1)$ & $26(51.0)$ & 0.723 \\
\hline & Male & $18(52.9)$ & $25(49.0)$ & - \\
\hline \multirow[b]{2}{*}{ Child's birth order; n (\%) } & First & $9(26.5)$ & $25(49.0)$ & 0.115 \\
\hline & Median & $5(14.7)$ & $5(9.8)$ & - \\
\hline Planned pregnancy; n (\%) & Yes & $24(70.6)$ & $39(76.5)$ & - \\
\hline \multirow{2}{*}{$\begin{array}{l}\text { Maternal psychiatric support } \\
\text { status; } n(\%)\end{array}$} & No & $31(91.2)$ & $48(94.1)$ & 0.679 \\
\hline & Yes & $3(8.8)$ & $3(5.9)$ & - \\
\hline Care at 0-3 months; $n(\%)$ & Mother & $29(85.3)$ & $36(70.6)$ & 0.143 \\
\hline \multirow{6}{*}{ Breastfeeding duration; $\mathrm{n}(\%)$} & None & $1(2.9)$ & $1(2.0)$ & 0.420 \\
\hline & $<3$ mths & $3(8.8)$ & $4(7.8)$ & - \\
\hline & $3-6$ mths & $6(17.6)$ & $2(3.9)$ & - \\
\hline & $6-12$ mths & $6(17.6)$ & $11(21.6)$ & - \\
\hline & $12-24$ mths & $14(41.2)$ & $25(49.0)$ & - \\
\hline & $\geq 24$ mths & $4(11.8)$ & $8(15.7)$ & - \\
\hline \multirow{2}{*}{ Birth weight $(n=66)$} & Mean \pm SD & $2704.19 \pm 874.54$ & $3223.43 \pm 508.69$ & 0.006 ** \\
\hline & Median (min-max) & $2800(1050-4500)$ & $3200(2200-4500)$ & - \\
\hline
\end{tabular}

${ }^{*} \mathrm{p}<0.05,{ }^{* *} \mathrm{p}<0.01, \mathrm{SD}:$ Standart deviation, Min: Minimum, Max: Maximum 
be significantly higher in the malnourished group (Table 4).

\section{Correlation of Socio-demographic Characteristics with Malnutrition Severity}

The rate of the education level of the fathers of moderate/ severe cases as a primary school or below was found to be statistically significantly higher than the fathers of mild cases $(p=0.005)$.

The comparison of the two groups in terms of the income level found a significantly high rate of "minimum wage" in moderate/severe cases ( $p=0.037$ ) (Table 5).

\section{DISCUSSION}

Our study compared the mothers of malnourished children with the mothers of the control group in terms of sociodemographic characteristics, social support, domestic violence, and psychiatric symptoms.

Insufficient weight gain is one of the common reasons for pediatric outpatient clinic visits. Our study found no illnessrelated organic cause, including micronutrient deficiencies, in approximately one-fourth (26.7\%) of the patients who were diagnosed with malnutrition. Therefore, revealing the

Table 3. MSPSD, SDVAW and SCL-90 total and subscale scores comparison of the two groups

\begin{tabular}{|c|c|c|c|c|}
\hline TOTAL & & Malnourished $(n=34)$ & Control $(n=51)$ & $p$ \\
\hline \multirow{2}{*}{ MSPSD } & Mean \pm SD & $52.97 \pm 19.61$ & $62.45 \pm 17.74$ & $0.031 *$ \\
\hline & Median (min-max) & $55.50(19-84)$ & $61(19-84)$ & - \\
\hline \multirow{2}{*}{ SDVAW } & Mean \pm SD & $74.24 \pm 8.90$ & $73.53 \pm 5.83$ & 0.685 \\
\hline & Median (min-max) & $76(50-87)$ & $73(62-87)$ & - \\
\hline \multirow{2}{*}{ SCL-90 } & Mean \pm SD & $0.71 \pm 0.62$ & $0.59 \pm 0.51$ & 0.551 \\
\hline & Median (min-max) & $0.50(0-2.2)$ & $0.50(0-2.3)$ & - \\
\hline \multirow{2}{*}{ SUBSCALE } & & Malnourished $(n=34)$ & Control $(n=51)$ & \multirow{2}{*}{$p$} \\
\hline & & n (\%) & n (\%) & \\
\hline \multirow{2}{*}{ SCL general symptom score } & Normal & $29(85.3)$ & $48(94.1)$ & 0.257 \\
\hline & High & $5(14.7)$ & $3(5.9)$ & - \\
\hline \multirow{2}{*}{ Somatization } & Normal & $30(88.2)$ & $47(92.2)$ & 0.708 \\
\hline & High & $4(11.8)$ & $4(7.8)$ & - \\
\hline \multirow{2}{*}{ Obsession } & Normal & $27(79.4)$ & $45(88.2)$ & 0.268 \\
\hline & High & $7(20.6)$ & $6(11.80)$ & - \\
\hline \multirow{2}{*}{ Interpersonal sensitivity } & Normal & $27(79.4)$ & $47(92.2)$ & 0.107 \\
\hline & High & $7(20.6)$ & $4(7.80)$ & - \\
\hline \multirow{2}{*}{ Depression } & Normal & $28(82.4)$ & 47 (92.2) & 0.189 \\
\hline & High & $6(17.6)$ & $4(7.80)$ & - \\
\hline \multirow{2}{*}{ Anxiety } & Normal & $29(85.3)$ & $50(98.0)$ & $0.036^{*}$ \\
\hline & High & $5(14.7)$ & $1(2.0)$ & - \\
\hline \multirow{2}{*}{ Hostility } & Normal & $29(85.3)$ & $48(94.1)$ & 0.257 \\
\hline & High & $5(14.7)$ & $3(5.90)$ & - \\
\hline \multirow{2}{*}{ Phobic anxiety } & Normal & $31(91.2)$ & $51(100.0)$ & 0.061 \\
\hline & High & $3(8.8)$ & $0(0.0)$ & - \\
\hline \multirow{2}{*}{ Paranoid thought } & Normal & $29(85.3)$ & $47(92.2)$ & 0.474 \\
\hline & High & $5(14.7)$ & $4(7.8)$ & - \\
\hline \multirow{2}{*}{ Psychoticism } & Normal & 31 (91.2) & $48(94.1)$ & 0.679 \\
\hline & High & $3(8.8)$ & $3(5.9)$ & - \\
\hline
\end{tabular}

${ }^{*} \mathrm{p}<0.05$, SD: Standart deviation, Min: Minimum, Max: Maximum, MSPSS: Multidimensional scale of perceived social support, SDVAW: Scale for domestic violence against women, SCL-90: Symptom checklist-90 
Table 4. Comparison of malnutrition severity and MSPSD, SDVAW, SCL-90 total and subscales scores in the malnourished group

\begin{tabular}{|c|c|c|c|c|}
\hline & & \multicolumn{2}{|c|}{ Malnutrition Severity } & \multirow{3}{*}{$p$} \\
\hline & & Mild $(n=19)$ & Moderate/Severe $(n=15)$ & \\
\hline & & n (\%) & n (\%) & \\
\hline \multirow{2}{*}{ SCL general symptom score } & Normal & $18(94.7)$ & $11(73.3)$ & 0.146 \\
\hline & High & $1(5.3)$ & $4(26.7)$ & - \\
\hline \multirow{2}{*}{ Somatization } & Normal & $19(100.0)$ & $11(73.3)$ & $0.029 *$ \\
\hline & High & $0(0.0)$ & $4(26.7)$ & - \\
\hline \multirow{2}{*}{ Obsession } & Normal & $18(94.7)$ & $9(60.0)$ & $0.028 *$ \\
\hline & High & $1(5.3)$ & $6(40.0)$ & - \\
\hline \multirow{2}{*}{ Interpersonal sensitivity } & Normal & $18(94.7)$ & $9(60.0)$ & $0.028 *$ \\
\hline & High & $1(5.3)$ & $6(40.0)$ & - \\
\hline \multirow{2}{*}{ Depression } & Normal & $17(89.5)$ & $11(73.3)$ & 0.370 \\
\hline & High & $2(10.5)$ & $4(26.7)$ & - \\
\hline \multirow{2}{*}{ Anxiety } & Normal & $19(100.0)$ & $10(66.7)$ & $0.011 *$ \\
\hline & High & $0(0.0)$ & $5(33.3)$ & - \\
\hline \multirow{2}{*}{ Hostilitiy } & Normal & $18(94.7)$ & $11(73.3)$ & 0.146 \\
\hline & High & $1(5.3)$ & $4(26.7)$ & - \\
\hline \multirow[t]{2}{*}{ Phobic anxiety } & Normal & 19 (100.0) & $12(80.0)$ & 0.076 \\
\hline & High & $0(0.0)$ & $3(20.0)$ & - \\
\hline \multirow[t]{2}{*}{ Paranoid thought } & Normal & $18(94.7)$ & $11(73.3)$ & 0.146 \\
\hline & High & $1(5.3)$ & $4(26.7)$ & - \\
\hline \multirow[t]{2}{*}{ Psychoticism } & Normal & $19(100.0)$ & $12(80.0)$ & 0.076 \\
\hline & Yüksek & $0(0.0)$ & $3(20.0)$ & - \\
\hline
\end{tabular}

${ }^{*} \mathrm{p}<0.05$, MSPSS: Multidimensional scale of perceived social support, SDVAW: Scale for domestic violence against women, SCL-90: Symptom checklist-90

underlying maternal-based familial factors opens up an important area in solving the problem.

Wasting is the most common type of malnutrition in our study group. Wasting, which is an indicator of acute malnutrition that has not yet become chronic, is seen more frequently unlike other countries and global data, shows that rapid treatment response can be obtained with the early diagnosis since most of the published data are from underdeveloped countries and Turkey is among the developing countries (14-16). In addition, our study is regional in nature and not general in Turkey. Mild malnutrition constitutes the majority of cases $(55.9 \%)$ due to similar reasons in the degree of malnutrition that increases the expectation of a positive response in terms of treatment because severe malnutrition causes high morbidity and mortality and constitutes the basis for infectious and non-infectious deaths $(17,18)$.

Many studies on the relationship between malnutrition and the educational level of parents were reported in the literature (19-21). The literature revealed that the education level was lower in parents of children with malnutrition compared to that of the control group due to the high level of education of mothers that will increase their interest and experience in feeding their children and feed their children more consciously. In addition, the comparison of the parents' education levels with the severity of malnutrition revealed that the father's education level was lower in moderate/severe cases. Unlike the education level of the mother, the education level of the father was found to be associated with both malnutrition in the child and the severity of the malnutrition in our study. Father's education is important because he is the decision-maker of the family and his decisions can have a significant impact on children's health (22).

Many studies in the literature have shown that the income level of the family is an important factor affecting malnutrition in the child $(23,24)$. Our study showed that the income level of families of children with malnutrition was 
Tablo 5. Correlation of sociodemographic characteristics with malnutrition severity

\begin{tabular}{|c|c|c|c|c|}
\hline & & \multicolumn{2}{|c|}{ Malnutrition Severity } & \multirow[b]{2}{*}{$\mathrm{p}$} \\
\hline & & Mild $(n=19)$ & $\begin{array}{l}\text { Moderate- } \\
\text { Severe }(n=15)\end{array}$ & \\
\hline \multirow{2}{*}{ Age (year) } & Mean \pm SD & $34.95 \pm 6.84$ & $36 \pm 6.63$ & 0.655 \\
\hline & Median (min-max) & $34(24-49)$ & $38(20-46)$ & - \\
\hline \multirow{3}{*}{ Mother education; n (\%) } & None & $4(21.1)$ & $6(40)$ & 0.584 \\
\hline & Primary school & $11(57.9)$ & $7(46.7)$ & - \\
\hline & High school-University & $4(21.1)$ & $2(13.3)$ & - \\
\hline \multirow{2}{*}{ Father education; n (\%) } & None-primary school & $11(57.9)$ & $15(100.0)$ & $0.005^{\star \star}$ \\
\hline & High school-university & $8(42.1)$ & $0(0.0)$ & - \\
\hline \multirow{3}{*}{ Mother working; n (\%) } & Housewife & $18(94.7)$ & $13(86.7)$ & 0.716 \\
\hline & Full time & $0(0.0)$ & $1(6.7)$ & - \\
\hline & Retired & $1(5.3)$ & $1(6.7)$ & - \\
\hline \multirow{2}{*}{ Father working; n (\%) } & No & $8(42.1)$ & $4(26.7)$ & 0.350 \\
\hline & Yes & $11(57.9)$ & $11(73.3)$ & - \\
\hline \multirow{2}{*}{ Marital status; n (\%) } & Married & $19(100.0)$ & $14(93.3)$ & 0.441 \\
\hline & Divorced & $0(0.0)$ & $1(6.7)$ & - \\
\hline \multirow{3}{*}{ Income status; n (\%) } & $<$ Minimum wage & $6(31.6)$ & $2(13.3)$ & $0.037^{\star}$ \\
\hline & Minimum wage & $3(15.8)$ & $9(60)$ & - \\
\hline & $\geq$ Minimum wage & $10(52.6)$ & $4(26.7)$ & - \\
\hline \multirow{3}{*}{ People live with; n (\%) } & Nuclear family & $14(73.7)$ & $11(73.3)$ & 1.000 \\
\hline & Exteneded family & $3(15.8)$ & $3(20)$ & - \\
\hline & Single parent with children & $2(10.5)$ & $1(6.7)$ & - \\
\hline \multirow[t]{2}{*}{ Marriage age } & Mean \pm SD & $21.63 \pm 5.37$ & $21.07 \pm 5.13$ & 0.758 \\
\hline & Median (min-max) & $20(15-38)$ & $20(13-33)$ & - \\
\hline \multirow[t]{2}{*}{ Maternal age } & Mean \pm SD & $23.42 \pm 5.48$ & $24.33 \pm 5.63$ & 0.637 \\
\hline & Median (min-max) & $24(17-40)$ & $24(16-34)$ & - \\
\hline \multirow[t]{2}{*}{ Number of siblings } & Mean \pm SD & $2.84 \pm 1.42$ & $2.67 \pm 1.29$ & 0.943 \\
\hline & Median (min-max) & $3(1-7)$ & $3(1-5)$ & - \\
\hline
\end{tabular}

lower than that of the control group. In addition, the income level of the moderate/severe group was lower in severe malnutrition than the group with mild malnutrition. These results suggest that low income is a significant risk factor that may affect the child's access to adequate food intake for growth and development that deepen the severity of malnutrition. Several studies have also shown that the young maternal age at birth and the number of children is associated with malnutrition $(25,26)$. Our study did not find any difference between the two groups in terms of young maternal age at birth and the number of children.
Many studies have shown that low birth weight and preterm birth increase the risk of developing malnutrition in later life $(27,28)$. Similar to the literature, we found that low birth weight in the malnourished group was statistically significantly higher than the cases in the control group $(p=0.006)$. In addition, preterm birth was higher in the malnourished group, whereas term birth was higher in the control group, which was statistically significant $(p=0.011)$. This is valid for babies who did not catch up with their peers expected at the age of two due to insufficient micronutrient support and lack of care $(29,30)$. Prenatal care both for 
maternal and infant health is also important. The quality and number of prenatal care received by pregnant women should also be increased to reduce the frequency of lowbirth-weight babies.

Mother's mental health not only affects children's long-term emotional, cognitive, and behavioral state but also impacts the child's physical health and development. Studies have shown that healthy maternal behavior and attitude have an important role in providing healthy nutrition in children $(31,32)$. Unlike the literature, the SCL-90 total and subscale scores did not differ between mothers of malnourished and control groups in our study. However, the frequency of getting a high score on the SCL-90 anxiety subscale in the mothers of the malnourished group was found to be statistically high $(p=0.036)$. These findings drew attention to significantly higher anxiety levels of these mothers. In addition, mothers of children with moderate/severe malnutrition were found to have a frequency of getting high scores on the SCL-90 anxiety, somatization, $O C D$, and interpersonal sensitivity subscales, which suggest that psychiatric symptoms in the mother may not only cause malnutrition but also determines the severity of malnutrition.

Many studies have shown that the children of depressed mothers were at an increased risk of malnutrition $(33,34)$. Our study found that SCL-90 depression subscale scores are higher in the mothers of the malnourished group but not significant, which may be due to the generally high prevalence of mental health problems among women in Turkey (35). However, the comparison of malnutrition severity and depression scores found that SCL-90 depression subscale scores were statistically significant in the moderate/severe group than that of the mild group, which shows that maternal depression impacts the child's malnutrition and determines the severity of malnutrition. Evaluating and intervening with the mothers of mildly malnourished children for depressive symptoms may prevent the worsening of malnutrition.

Studies have shown that insufficient social support is one of the risk factors for malnutrition in children $(36,37)$. The MSPSD scores of the mothers of the malnourished group were found to be statistically significantly lower compared to that of the control group $(p=0.031)$. Low social support is known to be associated with other psychiatric diseases, especially depression $(38,39)$. Based on our findings above, low social support may affect malnutrition as a predisposition for psychiatric disorders in the mother, as well as its effect on child nutrition. Having social support is an important factor in recognizing and intervening in domestic violence. The effect of domestic violence on child malnutrition has been shown in many studies (40). Our study found no difference between the two groups in terms of domestic violence.

\section{Study Limitations}

The small sample size is a limitation of our study.

\section{CONCLUSION}

In most societies, mothers are primarily responsible for feeding young children, which is a challenging task that requires good mental health maintenance. Mothers' mental health problems can contribute to negative consequences for their children's health and well-being. Along with these findings, the education of parents, income level, social support, and mental health of the mother should be evaluated in the child presenting with malnutrition without an organic cause and should be directed for appropriate intervention.

\section{ETHICS}

Ethics Committee Approval: The study protocol was approved by the Ethics Committee University of Health Sciences Turkey, Bakırköy Dr. Sadi Konuk Training and Research Hospital (approved number: 2021/58; date: 01.02.2021).

Informed Consent: All patients agreed to participate in the study and written informed consents were obtained from each participant.

\section{Authorship Contributions}

Concept: M.E., S.Y., Design: M.E., S.Y., Data Collection Processing: T.Ç., S.Y., M.E., Analysis or Interpretation: M.E., S.Y., S.S.O., Writing: M.E., S.S.O.

Conflict of Interest: No conflict of interest was declared by the authors.

Financial Disclosure: The authors declared that this study received no financial support.

\section{REFERENCES}

1. Ijarotimi OS. Determinants of Childhood Malnutrition and Consequences in Developing Countries. Curr Nutr Rep 2013;2:12933.

2. Walker SP, Grantham-Mcgregor SM, Powell CA, Chang SM. Effects of growth restriction in early childhood on growth, $I Q$, and cognition at age 11 to 12 years and the benefits of nutritional supplementation and psychosocial stimulation. J Pediatr 2000;137:36-41.

3. Caballero B. Global patterns of child health: the role of nutrition. Ann Nutr Metab 2002;46 (Suppl)1:3-7.

4. UNICEF/WHO/World Bank Group joint child malnutrition estimates, Levels and Tends in Child Malnutrition https://www.who. int/nutgrowthdb/2018. 
5. Pelletier DL, Frongillo EA Jr, Schroeder DG, Habicht JP. The effects of malnutrition on child mortality in developing countries. Bull World Health Organ 1995;73:443-8.

6. Hendricks KM, Duggan C, Gallagher L, Carlin AC, Richardson DS, Collier SB, et al. Malnutrition in hospitalized pediatric patients. Current prevalence. Arch Pediatr Adolesc Med 1995;149:1118-22.

7. Lucarelli L, Sechi C, Cimino S, Chatoor I. Avoidant/Restrictive Food Intake Disorder: A Longitudinal Study of Malnutrition and Psychopathological Risk Factors From 2 to 11 Years of Age. Front Psychol 2018;9:1608.

8. Silveira KB, Alves JF, Ferreira HS, Sawaya AL, Florêncio TM. Association between malnutrition in children living in slums, maternal nutritional status, and environmental factors. J Pediatr 2010;86:215-20

9. Derogatis LR, Lipman RS, Covi L. SCL-90: an outpatient psychiatric rating scale--preliminary report. Psychopharmacology bulletin 1973:1;9:13-28.

10. Dağ I. Belirti Tarama Listesi (Scl-90-R)'nin Üniversite Öğrencileri için güvenirliği ve geçerliği [Reliability and validity of the Symptom Check List (SCL-90-R) for university students]. Türk Psikiyatri Dergisi 1991;2:5-12.

11. Zimet GD, Dahlem, NW, Zimet SG, Farley GK. The multidimensional scale of perceived social support. J Pers Assess 1998;52:30-41.

12. Eker $D$, Arkar $H$, Yaldız H. Factorial structure, validity, and reliability of revised form of the multidimensional scale of perceived social support. Türk Psikiyatri Dergisi 2001;12:17-25.

13. Kilic B. The determination of violence against domestic women and the role of the nurse. (Master's Thesis). Istanbul: Istanbul University: 1999.

14. Das S, Fahim SM, Islam MS, Biswas T, Mahfuz M, Ahmed T. Prevalence and sociodemographic determinants of householdlevel double burden of malnutrition in Bangladesh. Public Health Nutr 2019;22:1425-32.

15. Khambalia AZ, Lim SS, Gill T, Bulgiba AM. Prevalence and sociodemographic factors of malnutrition among children in Malaysia. Food Nutr Bull 2012;33:31-42.

16. Hossain S. Chowdhury PB, Biswas RK, Hossain A. Malnutrition status of children under 5 years in Bangladesh: A sociodemographic assessment. Children and Youth Service 2020;117.

17. Kwena AM, Terlouw DJ, de Vlas SJ, Phillips-Howard PA, Hawley WA, Friedman JF, et al. Prevalence and severity of malnutrition in pre-school children in a rural area of western Kenya. Am J Trop Med Hyg 2003;68(4 Suppl):94-9.

18. Maitland K, Berkley JA, Shebbe M, Peshu N, English M, Newton CR. Children with severe malnutrition: can those at highest risk of death be identified with the WHO protocol? PLoS Med 2006;3:e500.

19. Gupta MC, Mehrotra M, Arora S, Saran M. Relation of childhood malnutrition to parental education and mothers' nutrition related KAP. Indian J Pediatr 1991;58:269-74.

20. Islam MR, Rahman MS, Rahman MM, Nomura S, de Silva A, Lanerolle $\mathrm{P}$, et al. Reducing childhood malnutrition in Bangladesh: the importance of addressing socio-economic inequalities. Public Health Nutr 2020;23:72-82.

21. Tette EM, Sifah EK, Nartey ET. Factors affecting malnutrition in children and the uptake of interventions to prevent the condition. BMC Pediatr 2015;15:189.
22. Deshmukh PR, Sinha N, Dongre AR. Social determinants of stunting in rural area of Wardha, Central India. Med J Armed Forces India 2013;69:213-7.

23. Hong R. Effect of economic inequality on chronic childhood undernutrition in Ghana. Public Health Nutr 2007;10:371-8.

24. Davey S, Davey A, Adhish SV, Bagga R. Study of impact of sociocultural and economic factors of mothers on the nutritional status of their malnourished children in a rural area of Delhi, India. Int. J. Public Health 2015;4:162-7.

25. Wemakor A, Garti H, Azongo T, Garti H, Atosona A. Young maternal age is a risk factor for child undernutrition in Tamale Metropolis, Ghana. BMC Res Notes 2018;11:877.

26. Sezgin B, Akın A. Adölesan dönemi üreme sağlığı. Sağlık ve Toplum Dergisi 1998;34:27-36.

27. Barros FC, Huttly SR, Victora CG, Kirkwood BR, Vaughan JP. Comparison of the causes and consequences of prematurity and intrauterine growth retardation: a longitudinal study in southern Brazil. Pediatrics 1992;90(2 Pt 1):238-44.

28. Rahman A, lqbal Z, Bunn J, Lovel H, Harrington R. Impact of maternal depression on infant nutritional status and illness: a cohort study. Arch Gen Psychiatry 2004;61:946-52.

29. Hollo O, Rautava P, Korhonen T, Helenius H, Kero P, Sillanpää M. Academic achievement of small-for-gestational-age children at age 10 years. Arch Pediatr Adolesc Med 2002;156:179-87.

30. Ounsted M, Moar VA, Scott A. Growth and proportionality in early childhood. III. Differences between babies of low birthweight in well-nourished and malnourished populations. Early Hum Dev 1986;14:167-78.

31. Black RE, Allen LH, Bhutta ZA, Caulfield LE, de Onis M, Ezzati $M$, et al. Maternal and child undernutrition: global and regional exposures and health consequences. Lancet 2008;371:243-60.

32. Faruque AS, Ahmed AM, Ahmed T, Islam MM, Hossain MI, Roy SK, et al. Nutrition: basis for healthy children and mothers in Bangladesh. J Health Popul Nutr 2008;26:325-39.

33. Haithar S, Kuria MW, Sheikh A, Kumar M, Vander Stoep A. Maternal depression and child severe acute malnutrition: a case-control study from Kenya. BMC Pediatr 2018;18:289.

34. Surkan PJ, Kennedy CE, Hurley KM, Black MM. Maternal depression and early childhood growth in developing countries: systematic review and meta-analysis. Bull World Health Organ 2011;89:608-15.

35. Kose T. Gender, income and mental health: The Turkish case. PLoS One 2020;15:e0232344.

36. Adekunle L. The effect of family structure on a sample of malnourished urban Nigerian children. Food Nutr Bull 2005;26:2303.

37. Rikimaru T, Yartey JE, Taniguchi K, Kennedy DO, Nkrumah FK. Risk factors for the prevalence of malnutrition among urban children in Ghana. J Nutr Sci Vitaminol 1998:44:391-407.

38. Hefner J, Eisenberg D. Social support and mental health among college students. Am J Orthopsychiatry 2009;79:491-9.

39. Ünal S, Küey L, Güleç C, Bekaroğlu M, Evlice YE, Kırlı S. Depresif Bozukluklarda Risk Etkenleri. Klinik Psikiyatri 2002;5:8-15.

40. Sobkoviak RM, Yount KM, Halim N. Domestic violence and child nutrition in Liberia. Soc Sci Med 2012;74:103-11. 